\title{
Causes of admission and outcomes of brown hare (Lepus europaeus) leverets at wildlife rescue centres in the Czech Republic
}

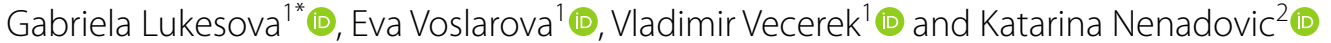

\begin{abstract}
Background: Wildlife rescue centres care for orphaned and injured young as an integral part of their work. However, inappropriate interventions in nature can have a negative effect on the survival of young hares, especially when the care of these young is not very successful. The aim of this study was to assess the number of brown hare leverets admitted to rescue centres in the Czech Republic in the period from 2010 to 2019, the causes of their admission to rescue centres and their outcomes.
\end{abstract}

Results: We evaluated the number of brown hare leverets admitted to rescue centres in the Czech Republic in the period from 2010 to 2019 and the outcomes associated with their leaving these rescue centres. We found that the number of brown hare leverets admitted increased during the monitored period ( $\mathrm{rSp}=0.6364, p<0.05)$. The most frequent reasons for admission were the admission of orphaned young (49.15\%), leverets brought needlessly (19.60\%) and leverets that had been bitten by other animals $(18.63 \%)$. More $(p<0.05)$ young admitted to rescue centres died (40.76\%) than were reared successfully and released back into the wild (32.40\%). Leverets that had been caught needlessly or orphaned and late-born leverets survived and could be released back into the wild (38.56, 34.51 and 52\%, respectively), while fatalities were recorded in most leverets bitten by another animal (65.05\%) or hit in a collision with a vehicle (97.06\%). Most young hares (76.92\%) that were exhausted or starved at the time of admission could not be saved.

Conclusions: Since only a small proportion of hares in a litter survive until adulthood in the wild, young animals being found and taken needlessly to rescue centres may harm the hare population. Our results show that only around one in three healthy young hares admitted to rescue centres are reared successfully. It is, in our opinion, of fundamental importance to the protection of brown hare leverets to inform the public of this issue and prevent needless interventions into natural rearing in the wild.

Keywords: Mammal, Orphan, Rehabilitation, Mortality, Release

*Correspondence: lukesovag@vfu.cz

1 Department of Animal Protection and Welfare and Veterinary Public Health, Faculty of Veterinary Hygiene and Ecology, University of Veterinary Sciences Brno, Brno, Czech Republic

Full list of author information is available at the end of the article

\section{Introduction}

The brown hare (Lepus europaeus) is a common species occurring in the Czech Republic and other European countries [1]. The degree of the threat to this species stated by the International Union for Conservation of Nature (2020) ranges from Least Concern to Near Threatened depending on the area in which it occurs. Hare populations are relatively isolated as a result of the mosaic distribution of the landscape divided by large roads, train 
tracks and towns [2]. Their natural habitat is in decline or significantly transformed by the extensive use of land for agriculture, which is reflected in a decline in the numbers of these animals [3, 4]. Furthermore, hares are often forced to cross roads when seeking new habitats, which leads to collisions with vehicles [5]. Several diseases and infections of parasitic origin [6] and natural predators [7] also play a large part in the decline in hare numbers, in addition to anthropogenic activity.

Although hares develop a large number of survival strategies [8], their mortality rate is extremely high, particularly among young in the first two weeks of life [9]. Hansen [10] reported a mortality rate of as much as $80 \%$ in leverets as a result of a shortage of suitable habitats. In their study, Karp and Gehr [11] reported an even lower survival rate in young brown hares, likewise due to the unsuitability of habitats. Litters are also affected negatively by excessive precipitation [12] and the occurrence of large numbers of parasites that cause a decline in the weight and hardiness of animals [6]. The mortality rate is also high among adult hares, which are affected by poaching, predation and the aforementioned collisions with road traffic [13]. Because this is a game animal, gamekeeping and other hunting activities also make their mark on hare populations $[14,15]$.

Caring for hares is far from easy despite developments made in veterinary medicine. Hares are animals that are extremely stress-sensitive, which has an impact on their health and results in high mortality [16], and for this reason, they have specific handling requirements [17]. Young hares can get in a negative energy balance as a result of stress and the refusal of food, which harms their health [18]. Rescue centres contribute to nature protection by helping to restore handicapped animals to health and return them to the wild, thereby compensating in part for the negative effects of anthropogenic activities on these animals.

This study aimed to assess the number of leverets admitted to rescue centres in the Czech Republic in the period from 2010 to 2019 and to assess the causes of their admission to rescue centres and their outcomes.

\section{Materials and methods}

We obtained data on handicapped animals admitted to rescue centres in the Czech Republic from the records of the Ministry of the Environment, which coordinates the activity of rescue centres. The subject of our evaluation was all brown hare leverets admitted to the rescue centres falling under the National Network of Rescue Centres of the Czech Republic in the period from 2010 to 2019 , as well as the reasons for their admission and their outcomes.

For purposes of evaluation, the leverets were divided into groups according to the individual years in which they were admitted, according to the causes of their admission, and according to the reasons for their removal from rescue centre records.

The causes for the admission of young hares were divided into the groups given in Table 1 . The reasons leading to their leaving rescue centres are shown in Table 2. The method of their division into these categories is following the instructions for recording handicapped animals in the Czech Republic. Animals that were still treated at the end of the period monitored in our study were not included in the analysis.

The data were evaluated by the statistical program UNISTAT 6.5 for Excel (Unistat Ltd., London, UK). Spearman's coefficient, which enabled the

Table 1 Reasons for the admission of brown hare leverets to rescue centres in the Czech Republic

\begin{tabular}{|c|c|c|}
\hline Reason for admission & Characteristics & Example \\
\hline Orphaned & Young that have lost their mother & A young hare found without its mother \\
\hline Caught needlessly & A young hare taken to a rescue centre without reason & A healthy, well fed young hare without obvious injury \\
\hline Bitten by another animal & Bite wound & $\begin{array}{l}\text { A young hare with bite injuries or seen being attacked by } \\
\text { e.g. a dog }\end{array}$ \\
\hline Injuries & Injuries, not including bite injuries & $\begin{array}{l}\text { Fractures, contusions, injuries caused by garden machin- } \\
\text { ery, etc. }\end{array}$ \\
\hline Road traffic & Young hare injured by a road vehicle & An injured young hare found by the road \\
\hline Late-born young & Young that are not mature in the autumn & Young of a low age found late in the year \\
\hline Infection & Young with signs of infection (including parasites) & Young showing signs of coughing, diarrhoea, etc. \\
\hline Exhaustion, starvation & $\begin{array}{l}\text { Young of low weight, dehydrated, with no signs of infec- } \\
\text { tion }\end{array}$ & Dehydrated, emaciated young \\
\hline Falls into sumps, chimneys, etc. & Falls into places from which young hares cannot escape & Young hare found in a recess from which it cannot escape \\
\hline Destroyed nests & Young found by a destroyed nest with no possible shelter & Young near a nest destroyed by agricultural machinery \\
\hline Other causes & Causes other than those given above & Shot, entangled in a foreign object, etc. \\
\hline
\end{tabular}


Table 2 Outcomes for brown hare leverets in rescue centres in the Czech Republic

\begin{tabular}{ll}
\hline Outcome & Description \\
\hline Release & $\begin{array}{l}\text { Young that recovered and were released back into their natural habitat } \\
\text { Young returned to the original nest they were taken from or added to } \\
\text { heturned to the nest or adopted }\end{array}$ \\
$\begin{array}{l}\text { heath } \\
\text { Euthanasia }\end{array}$ & Young that died in rescue centres (unassisted death) \\
Permanent captivity & Young that had to remain in captivity due to permanent disability \\
Escape & Young that escaped during rehabilitation \\
Unknown & Not specified \\
\hline
\end{tabular}

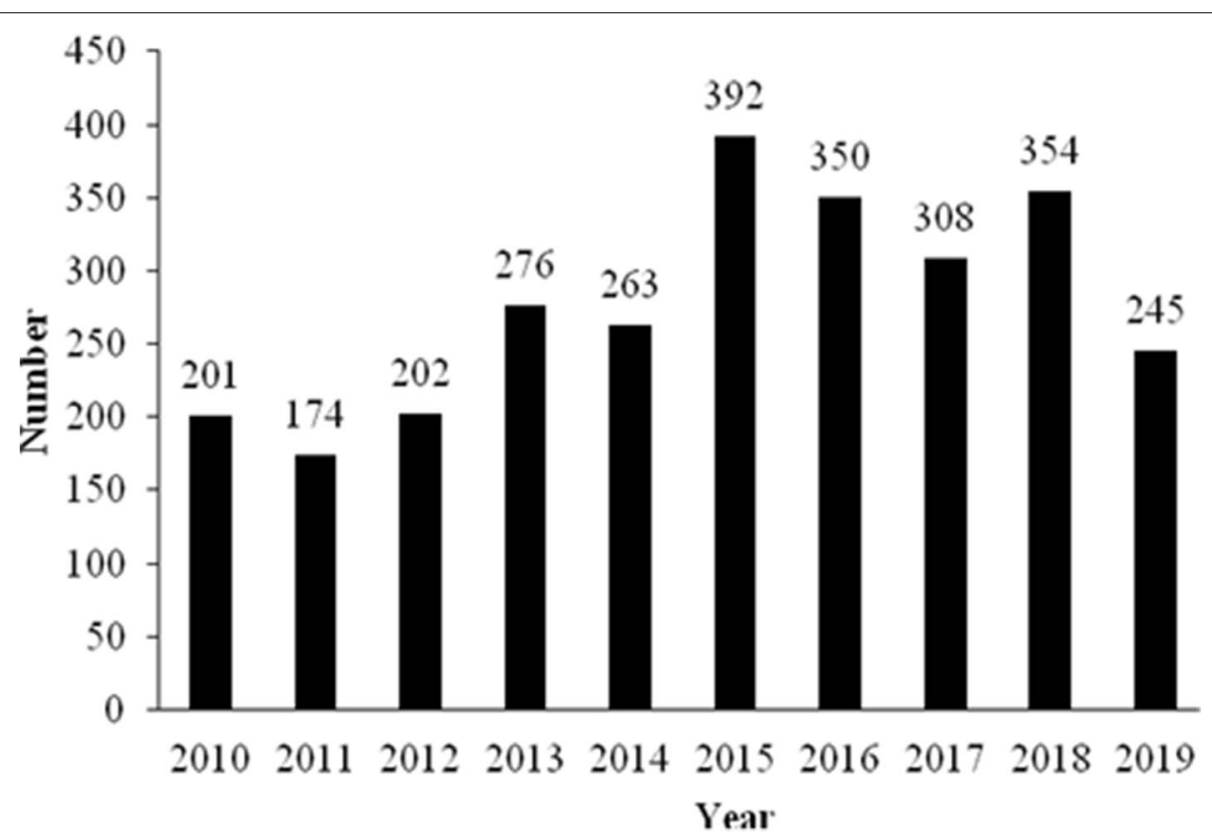

Fig. 1 Number of brown hare leverets admitted to rescue centres in the period 2010-2019

determination of a rank correlation coefficient, was used to evaluate the developmental trend of the figures in the years 2010 to 2019. A Chi-square test with Yates' correction using the $2 \times 2$ contingency table method was used for the evaluation of differences in frequencies in individual groups with numbers of individuals $>5$. A value of $<0.05$ was stipulated as statistically significant in the statistical tests used.

\section{Results}

A total of 2765 brown hare leverets were admitted to 34 rescue centres in the Czech Republic in the period from 2010 to 2019. We found an upwards trend in the number of young brown hares admitted to rescue centres in the Czech Republic during the studied period $(\mathrm{rSp}=0.6364$, $p<0.05$ ). Figure 1 depicts the number of brown hare leverets admitted to rescue centres in the Czech Republic in the individual years in the studied period.
Table 3 Number and percentage of the total number of brown hare leverets admitted to rescue centres in the Czech Republic in the years 2010 to 2019 by reasons for admission

\begin{tabular}{lll}
\hline Reason for admission & $\begin{array}{l}\text { young admitted } \\
(\boldsymbol{n}=\mathbf{2 7 6 5 )}\end{array}$ & \\
\cline { 2 - 3 } & number & $\%$ \\
\hline Orphaned & 1359 & $49.15^{\mathrm{a}}$ \\
Caught needlessly & 542 & $19.60^{\mathrm{b}}$ \\
Bitten by another animal & 515 & $18.63^{\mathrm{c}}$ \\
Injured & 78 & $2.82^{\mathrm{e}}$ \\
Road traffic & 34 & $1.23^{\mathrm{f}}$ \\
Late-born young & 25 & $0.90^{\mathrm{f}, \mathrm{g}}$ \\
Infection & 3 & $0.11^{\mathrm{i}}$ \\
Exhaustion, starvation & 13 & $0.47^{\mathrm{g}, \mathrm{h}}$ \\
Falls into sumps, chimneys, etc. & 8 & $0.29^{\mathrm{h}, \mathrm{i}}$ \\
Destroyed nests & 151 & $5.46^{\mathrm{d}}$ \\
Other causes & 37 & $1.34^{\mathrm{f}}$ \\
\hline
\end{tabular}

a-i different superscript letters indicate a statistically significant difference between percentages in the column $(p<0.05)$ 
Reasons for the admission of brown hare leverets to rescue centres from 2010 to 2019 are shown in Table 3. The most frequent reason for the admission of brown hare leverets to rescue centres was the admission of orphaned young (49.15\%) followed by the admission of young hares caught needlessly (19.60\%) and young hares bitten by another animal (18.63\%).

The outcomes for young brown hares in rescue centres are given in Table 4. The most frequent outcome for brown hare leverets at rescue centres was death (40.76\%), followed by release back into the wild (32.40\%). A substantial proportion of young hares (19.58\%) had to remain in permanent captivity after leaving the rescue centre. Euthanasia occurred in $3.29 \%$ of cases.

The division of brown hare leverets into groups by the reason for their admission to rescue centres and the

Table 4 Number and percentage of the total number of brown hare leverets admitted to rescue centres in the period 2010 to 2019 according to the outcomes

\begin{tabular}{lll}
\hline Outcome & \multicolumn{2}{l}{$\begin{array}{l}\text { number of young } \\
(\boldsymbol{n}=\mathbf{2 6 3 0 )}\end{array}$} \\
\cline { 2 - 3 } & number & $\%$ \\
\hline Release & 852 & $32.40^{\mathrm{b}}$ \\
Returned to the nest or adopted & 42 & $1.60^{\mathrm{e}}$ \\
Death & 1072 & $40.76^{\mathrm{a}}$ \\
Euthanasia & 103 & $3.29^{\mathrm{d}}$ \\
Permanent captivity & 515 & $19.58^{\mathrm{c}}$ \\
Escape & 9 & $0.34^{\mathrm{f}}$ \\
Unknown & 37 & $1.41^{\mathrm{e}}$ \\
\hline
\end{tabular}

a-f different superscript letters indicate a statistically significant difference between percentages in the column $(p<0.05)$ number of leverets released and those that died or were euthanized is given in Table 5. Brown hare leverets were released back into the wild most often in the case of admitted late-born young (52.00\%) and those admitted after falls into sumps or chimneys $(50.00 \%)$. The success rate was around a third in the case of orphaned young (34.51\%), needlessly caught young (38.56\%) and young admitted due to infectious diseases (33.33\%). Death and euthanasia occurred most frequently in young hares following collisions with road vehicles $(97.06 \%)$, bites by other animals (65.05\%), injuries (70.51\%) and animals suffering from exhaustion and starvation (76.92\%). However, also $36.06 \%$ of orphaned young and $30.44 \%$ of needlessly captured young died or were euthanized.

\section{Discussion}

The number of brown hare leverets admitted to Czech wildlife rescue centres increased during the period 2010 to 2019 . The finding that these were in many cases orphaned or needlessly captured young is particularly important. Even though the orphaned brown hare leverets and those needlessly captured are divided into two different groups, it is probable - because of the way of life of young hares - that at least some of the young believed to have been orphaned may have been needlessly captured. Young hares remain alone hidden in their nests, and their mother feeds them only once or twice a day, always in the same place and generally at the same time [19]. This survival strategy of young hiding quietly in their nests may arouse emotions in people who come across these young hares. They may then take them to rescue centres believing that they are orphaned, although these young do not, in reality, require help. It is far from easy to rear these young since the milk of hares has an

Table 5 The division of brown hare leverets into groups by the reason for their admission to rescue centres and the number of leverets released and those that died or were euthanized

\begin{tabular}{|c|c|c|c|c|c|}
\hline \multirow[t]{3}{*}{ Reason for admission } & \multirow{3}{*}{$\begin{array}{l}\text { Number of admitted } \\
(n=2765)\end{array}$} & \multicolumn{4}{|l|}{ Outcome } \\
\hline & & \multicolumn{2}{|c|}{ Released into the wild } & \multicolumn{2}{|c|}{ Euthanized or died } \\
\hline & & number & $\%$ & number & $\%$ \\
\hline Orphaned & 1359 & 469 & 34.51 & 490 & 36.06 \\
\hline Caught needlessly & 542 & 209 & 38.56 & 165 & 30.44 \\
\hline Bitten by another animal & 515 & 94 & 18.25 & 335 & 65.05 \\
\hline Injures & 78 & 16 & 20.51 & 55 & 70.51 \\
\hline Road traffic & 34 & 1 & 2.94 & 33 & 97.06 \\
\hline Late-born young & 25 & 13 & 52.00 & 12 & 48.00 \\
\hline Infection & 3 & 1 & 33.33 & 2 & 66.67 \\
\hline Exhaustion, starvation & 13 & 1 & 7.69 & 10 & 76.92 \\
\hline Falls into sumps, chimneys, etc. & 8 & 4 & 50.00 & 1 & 12.50 \\
\hline Destroyed nests & 151 & 37 & 24.50 & 63 & 41.72 \\
\hline Other causes & 37 & 7 & 18.92 & 9 & 24.32 \\
\hline
\end{tabular}


extremely specific composition [20]. Substituting rabbit mothers for hare mothers is not entirely appropriate as the physiology of digestion and food intake in these two species show considerable differences [21]. Female hares also choose a special diet during lactation [22], and that is the reason why it is difficult to estimate correctly the ideal composition of milk. It is a problem mentioned by authors in a large number of wild animal species and the rearing of their young [23, 24]. The stress caused by a change of environment and by human handling also takes its toll on the health of young and may also harm attempts at their rearing [25]. This is also confirmed by the results of our study, in which only around a third of young hares admitted to rescue centres as orphaned or needlessly captured were successfully reared and released back into the wild, while around another third of these young animals died or were euthanized at wildlife rescue centres.

Bites by another animal were also a frequent reason for admission to wildlife rescue centres, as hare nests on the ground can easily be found both by domestic animals [26] and by natural predators, primarily foxes [27]. These animals could usually not be saved, and death or euthanasia occurred in $65 \%$ of cases. An even lower success rate was recorded in young hares admitted with other injuries or following a collision with a vehicle, for which the mortality rate amounted to 70 and $97 \%$, respectively. The high mortality rate in the case of hares hit by a vehicle is not particularly surprising, as vehicles cause severe injuries to wild animals that are often incompatible with the treatment of any kind or any chance of survival, and are a frequent cause of the death of animals at rescue centres [28]. The frequency of these events may be an indirect index of hare population abundance.

Infection was listed as a reason for admission in only 3 animals. We suppose that only leverets with clinically obvious symptoms of infection (e.g. diarrhoea or respiratory symptoms, eye discharge, etc.) were listed in this category. Upon admission to the rescue centre, animals were not subjected to any specific diagnostic tests and thus, presence of infection in animals without clinical signs could not be detected. Alternatively, the leverets might have been brought to the rescue centres so young that no infection has yet occurred.

Many of the young hares taken to wildlife rescue centres were starved and emaciated and could not be saved, which may indicate that prompt intervention is important when young animals really do need help. In the case of hares, however, a correct assessment of the situation demands observation for a relatively long time, as mother hares visit their young extremely rarely over the course of any given day [19]. There is also the question of what causes the high percentage of animals that cannot be released back into the wild and that remain in permanent captivity (as was the case for $19.58 \%$ of individuals in our study) and what are the reasons for this when the animals taken to rescue centres are healthy. Such data are, however, not available in the rescue centre records. In the case of young animals reared in rescue centres and released back into the wild, it would also be appropriate to ascertain the rate of survival of these reared animals in the wild [13] and whether this factor, i.e. rearing in captivity, has any negative influence on their further survival in the wild.

There is a high mortality rate in young hares in the wild in the first weeks of life, previous studies reported leveret mortality ranging from $65 \%$ [9] to $84 \%$ [11] in the first month. Thus, it is particularly important to limit the factors that further contribute to their mortality. This involves, first and foremost, greater availability of suitable habitats, limiting losses on the roads and, perhaps most importantly, educating the public. Since orphaned leverets and leverets taken to rescue centres needlessly made up the largest proportion of young hares admitted to rescue centres in the Czech Republic, public education could help reduce these unnecessary interventions in the rearing of young whose chance of being released back into the wild is, according to our results, relatively low.

\section{Conclusion}

Information on brown hare leverets admitted to wildlife rescue centres in the Czech Republic and the fate that awaits them reveal the principal risks to these animals in the wild and highlight the fact that the hare is a species subjected to a strong selection, both natural and artificial, as demonstrated by the difficulties it encounters in different environmental contexts, and especially those that are anthropized and/or subject to intensive agriculture. Public education would appear fundamental because of the large number of young animals that are probably taken to rescue centres entirely needlessly (including young declared as orphaned). Spreading awareness among the general public of how young hares are reared in the wild, where the absence of the mother in the nest need not be a sign of orphaned young, may prevent the unnecessary collection of young. It is far from easy to meet the specific demands of the rearing of leverets in captivity, and this leads to a low success rate even in the case of healthy young hares admitted to rescue centres. The chance of survival is minimal in the case of injured or otherwise weakened young, thus our efforts should be directed, first and foremost, at assuring conditions for rearing in the natural environment and protection against anthropogenic influences. 


\section{Acknowledgements}

We would like to thank the Ministry of the Environment of the Czech Republic for providing data for this study.

\section{Conflict of interest}

The authors declare that they have no conflict of interest.

\section{Authors' contributions}

Conceptualization, G.L. and V.V.; methodology, G.L. and E.V; validation, V.V.; formal analysis, G.L., K.N. and E.V.; Writing-original draft preparation, G.L. and E.V.; writing-review and editing, V.V. and K.N.; visualization, G.L. and E.V.; supervision, V.V.; Funding acquisition, V.V. All authors have read and agreed to the published version of the manuscript.

\section{Funding}

This study was supported by ITA VFU Brno (Project No. FVHE/Necerek/ITA2020).

\section{Availability of data and materials}

Availability of data section of this manuscript in the Figshare repository DOI https://doi.org/10.6084/m9.figshare.14871975 in https://figshare.com/s/026fb 318 effd67aee 1 b8

\section{Declarations}

\section{Ethics approval and consent to participate}

All methods were performed in accordance with the relevant guidelines and regulations. The study was carried out in compliance with the ARRIVE quidelines. The data for analysis were obtained retrospectively from the national database archived by the Ministry of the Environment of the Czech Republic with the consent of the person in charge of data collection. No handling of animals related to research was carried out.

\section{Consent for publication}

Not applicable.

\section{Competing interests}

The authors declare that they have no competing interests.

\section{Author details}

${ }^{1}$ Department of Animal Protection and Welfare and Veterinary Public Health, Faculty of Veterinary Hygiene and Ecology, University of Veterinary Sciences Brno, Brno, Czech Republic. ${ }^{2}$ Department of Animal Hygiene, Faculty of Veterinary Medicine, University of Belgrade, Bulevar oslobodjenja 18 Belgrade 11000, Serbia.

Received: 15 July 2021 Accepted: 29 December 2021

Published online: 15 January 2022

\section{References}

1. IUCN Red List. Lepus europaeus [online]. [vid. 1. 3. 2021]. 2020. Available from: https://www.iucnredlist.org/search?query=zaj\%C3\%ADc\% 20poln\%C3\%AD\&searchType=species

2. Keken Z, Kušta T, Langer P, Skaloš J. Landscape structural changes between 1950 and 2012 and their role in wildlife-vehicle collisions in the Czech Republic. Land Use Policy. 2016:59:543-56.

3. Sliwinski K, Ronnenberg K, Jung K, Strauß E, Siebert U. Habitat requirements of the European brown hare (Lepus europaeus Pallas 1778) in an intensively used agriculture region (Lower Saxony, Germany). BMC Ecol. 2019:19:31.

4. Edwards PJ, et al. Review of the factors affecting the decline of the European brown hare, Lepus europaeus (Pallas, 1778) and the use of wildlife incident data to evaluate the significance of paraquat. Agric Ecosyst Environ. 2000;79:95-103.

5. Pépin D, Angibault JM. Selection of resting sites by the European hare as related to habitat characteristics during agricultural changes. Eur J Wildl Res. 2007;53:183-9.

6. Chroust K, Vodnansky M, Pikula J. Parasite load of European brown hares in Austria and the Czech Republic. Vet Med. 2012;57:551-8.
7. Angelici FM, Riga F, Boitani L, Luiselli L. Fate of captive-reared brown hares Lepus europaeus released at a mountain site in Central Italy. Wildl Biol. 2000;6:173-8.

8. Hutchings MR, Harris S. Does hunting pressure affect the flushing behaviour of brown hares (Lepus europaeus)? J Zool. 1995:237:663-7.

9. Voigt U, Siebert U. Survival rates on pre-weaning European hares (Lepus europaeus) in an intensively used agricultural area. Eur J Wild Res. 2020;66:67

10. Hansen K. Reproduction in European hare in a Danish farmland. Acta Theriol. 1992;37:27-40.

11. Karp D, Gehr B. Bad hare day: very low survival rate in brown hare leverets. Wildl Biol. 2002;2:wlb.00645.

12. Baudains TP, Lloys P. Habituation and habitat changes can moderate the impacts of human disturbance on shorebird breeding performance. Anim Conserv. 2007;10:400-7

13. Misiorowska M, Wasilewski M. Spatial organisation and mortality of released hares -preliminary results. Ann Zool Fenn. 2008;45:286-90.

14. Marboutin E, et al. Population dynamics in European hare: breeding parameters and sustainable harvest rates. J Appl Ecol. 2003;40:580-91.

15. Butterworth $A$, Turner KME, Jennings N. Minimising orphaning in the brown hare Lepus europaeus in England and Wales: should a close season be introduced. Wildl biol. 2017;1:2017 Available from: https://doi.org/10. 2981/wlb.00279.

16. Stocker L. Practical wildlife care. 2nd ed. Oxford: Blackwell Pub; 2005. p. 335.

17. Paci G, Ferretti M, Bagliacca M. Reducing visual stimulations in European hares (Lepus europaeus Pallas) captured for translocation. Ital J Anim Sci. 2012;11:e51.

18. Hackländer K, Arnold W, Ruf T. Postnatal development and thermoregulation in the precocial European hare (Lepus europaeus). J Comp Physiol B. 2002:172:183-90.

19. Broekhuizen S, Maaskamp F. Behaviour of does and leverets of the European hare (Lepus europaeus) whilst nursing. J Zool Lond. 1980;191:487-501.

20. Valencak TG, et al. Peak energy turnover in lactating European hares: the role of fat reserves. J Exp Biol. 2009:212:231-7.

21. Stott P. Comparisons of digestive function between the European hare (Lepus europaeus) and the European rabbit (Oryctolagus cuniculus): mastication, gut passage, and digestibility. Mamm Biol. 2008;73:276-86.

22. Popescu FD, et al. Effects of season and reproductive state on lipid intake and fatty acid composition of gastrointestinal tract contents in the European hare. J Comp Physiol B. 2011:181:681-9.

23. Lukešová G, Voslarova $E$, Vecerek V, Vucinic M. Trends in intake and outcomes for European hedgehog (Erinaceus europaeus) in the Czech rescue centers. PLoS One. 2021;16:e0248422.

24. Molina-López RA, Mañosa S, Torres-Riera A, Pomarol M, Darwich L. Morbidity, outcomes and cost-benefit analysis of wildlife rehabilitation in Catalonia (Spain). PLoS One. 2017;12:e0181331.

25. Paci G, et al. Stress evaluation in hares (Lepus europaeus Pallas) captured for traslocation. Ital J Anim Sci. 2006;5:175-81.

26. Woods M, Mcdonald RA, Harris S. Predation of wild life by domestic cats Felis catus in Great Britain: predation of wildlife by domestic cats. Mammal Rev 2003:33:174-88.

27. Reynolds JC, Tapper SC. Predation by foxes Vulpes vulpes on brown hares Lepus europaeus in central southern England, and its potential impact on annual population growth. Wildl Biol. 1995;1:145-58.

28. Crespo Martínez J, Izquierdo Rosique A, Surroca RM. Causes of admission and final dispositions of hedgehogs admitted to three wildlife rehabilitation centers in eastern Spain. Hystrix. 2014;25:107-10.

\section{Publisher's Note}

Springer Nature remains neutral with regard to jurisdictional claims in published maps and institutional affiliations. 